\title{
ANALISIS FAKTOR PELAYANAN ANTENATAL TERPADU DI WILAYAH KERJA PUSKESMAS TEMBILAHAN HULU
}

\author{
${ }^{1)}$ Sandra Harianis, ${ }^{2)}$ Mia Ritasari, ${ }^{3)}$ Dewi Erlina Asrita Sari ${ }^{4)}$ Madinah \\ Program Studi DIII Kebidanan, Akademi Kebidanan Husada Gemilang \\ Jl. Pendidikan Tembilahan - Inhil - Riau - Indonesia \\ E-mail : ${ }^{1)}$ sandraharianis880099@ gmail.com, ${ }^{2)}$ mia.ritasaro@yahoo.com, ${ }^{3)}$ deas_fardha@yahoo.com, \\ 4) madinahdina14@gmail.com
}

Kata Kunci:

Anc, terpadu

Keywords:

Antenatal care, integrated

\section{Info Artikel}

Tanggal dikirim: 3-12-2019

Tanggal direvisi: $23-1-2020$

Tanggal diterima: 23-1-2020

DOI : $10.36341 /$ jomis.v4i1.1078

Attribution-NonCommercial 4.0

$\underline{\text { International. Some rights reserved }}$

\begin{abstract}
ABSTRAK
Kesehatan ibu hamil masih menjadi masalah kesehatan nasional. Pelayanan Ante Natal Care (ANC) terpadu dengan 10 standar dapat meningkatkan kesehatan ibu dan janin. Namun, beberapa tahun terakhir komplikasi kehamilan dan persalinan semakin meningkat yang seharusnya dapat diidentifikasi secara dini dengan ANC yang tepat. Penelitian ini bertujuan untuk menggali pelaksanaan ANC 10 standar dan hambatan dalam pelaksanaannya. Penelitian ini menggunakan rancangan kualitatif dengan pendekatan fenomenologis. Penelitian dimulai dengan pengumpulan data kualitatif melalui focus group discussion (FGD) dan wawancara mendalam serta pengumpulan data kuantitatif melalui pengisian kuesioner pada bulan OktoberNovember 2018 di wilayah kerja Puskesmas Tembilahan Hulu. Sampel penelitian ini adalah seluruh bidan puskesmas Tembilahan Hulu dan ibu hamil yang diambil secara acak sebanyak 138 orang. Temuan penelitian ini diketahui 35 dari $138(25,4 \%)$ ibu hamil mendapat pelayanan ANC 10 standar secara lengkap. Timbang BB dan ukur TB $(86,23 \%)$, ukur tekanan darah $(100 \%)$, nilai status gizi $(88,41 \%)$, ukur TFU $(85,51 \%)$, nilai presentasi janin $(81,88 \%)$, srining T $(81,16 \%)$, tablet Fe $(71,01 \%)$, pemeriksaan labor $(81,88 \%)$, tatalaksana kasus $(82,61 \%)$, dan temu wicara $(69,57 \%)$. Hambatan bidan adalah sarana dan prasarana tidak memadai serta lemahnya ketermpilan bidan dalam melaksanakan standar. Perlunya monitoring dan evaluasi pemegang program KIA serta bimbingan dan pelatihan pelayanna ANC terpadu bagi seluruh bidan.
\end{abstract}

\begin{abstract}
(
The health of pregnant women is still a national health problem. Ante Natal Care (ANC) services integrated with 10 standards can improve maternal and fetal health. However, in recent years complications of pregnancy and childbirth have increased which should be identified early with the right ANC. This study aims to explore the implementation of ANC 10 standards and obstacles in their implementation. This study uses a qualitative design with a phenomenological approach. The study began with qualitative data collection through focus group discussion (FGD) and indepth interviews and quantitative data collection through filling out questionnaires in OctoberNovember 2018 in the working area of the Upper Tembilahan Health Center. The sample of this study was all midwives at the Tembilahan Hulu health center and pregnant women were randomly taken as many as 138 people. The findings of this study note 35 out of 138 (25.4\%) pregnant women received standard $A N C 10$ services in full. Weigh $B B$ and measure $T B$ $(86.23 \%)$, measure blood pressure (100\%), nutritional status $(88.41 \%)$, measure TFU $(85.51 \%)$, value of fetal presentation (81.88\%), srining $T$ (81.16\%), Fe tablets $(71.01 \%)$, labor checks $(81.88 \%)$, case management (82.61\%), and speech meetings (69.57\%). The obstacle of midwives is inadequate facilities and infrastructure and the weak skills of midwives in implementing standards. The need for monitoring and evaluation of KIA program holders and guidance and training for integrated ANC servants for all midwives.
\end{abstract}

\section{PENDAHULUAN}

Secara nasional, akses masyarakat kita terhadap pelayanan kesehatan ibu dan anak cenderung membaik. Dimana tren angka kematian ibu, angka kematian bayi, cakupan kunjungan antenatal, cakupan persalinan, nifas dan neonatus mengalami kenaikan yang cukup signifikan. Namun demikian, jika dibandingkan dengan target millenium development goals (MDG) pada tahun 2015, angka kematian ibu masih jauh dari angka yang ditargetkan (Kemenkes, 2016) 
Berbagai upaya telah diprogramkan pemerintah untuk mengatasi, memperbaiki, dan meningkatkan kualitas pelayanan kesehatan Ibu dan Anak, salah satunya yaitu dengan pelayanan antenatal terpadu. Pelayanan antenatal terpadu merupakan pelayanan antenatal yang dilaksanakan secara komprehensif mencakup upaya promotif, preventif, sekaligus kuratif dan rehabilitatif, yang meliputi pelayanan KIA, gizi, pengendalian penyakit menular (imunisasi, HIV/AIDS, TB, malaria, penyakit menular seksual), penanganan penyakit tidak menular serta beberapa program lokal dan spesifik lainnya sesuai dengan kebutuhan program.

Dalam pelayanan antenatal terpadu, seharusnya tenaga kesehatan dapat memastikan bahwa kehamilan berlangsung normal, mampu mendeteksi dini masalah dan penyakit yang dialami ibu hamil, melakukan intervensi secara adekuat sehingga ibu hamil siap untuk menjalani persalinan normal. Untuk dapat mengidentifikasi apakah kehamilan berlangsung normal atau dengan komplikasi, maka tenaga kesehatan khususnya bidan harus melaksanakan pelayanan antenatal sesuai standar.

Kriteria standar pelayanan antenatal telah ditetapkan dalam peraturan Menteri Kesehatan Republik Indonesia nomor 97 tahun 2014 yang terdiri dari 10 standar yaitu: 1) Timbang berat badan dan ukur tinggi badan; 2) Ukur tekanan darah; 3) Nilai status gizi; 4) Ukur tinggi fundus uteri; 5) Tentukan presentasi janin dan denyut jantung janin; 6) Skrining status immunisasi tetanus dan berikan immunisasi TT bila diperlukan; 7) Beri tablet tambah darah; 8) Periksa laboratorium (rutin dan khusus); 9) Tatalaksana/ penanganan kasus, dan; 10) Temu wicara. Untuk menyelenggarakan pelayanan antenatal terpadu yang sesuai dengan kriteria standar tersebut diperlukan suatu manajemen berbasis data baik dari tahap input, proses maupun output.

Program pelayanan antenatal terpadu ini juga sesuai dengan rekomendasi WHO dalam meningkatkan kualitas pelayanan antenatal. Dimana perawatan antenatal yang berkualitas dan tepat waktu merupakan praaktek avidance based yang terbukti dapat menyelamatkan nyawa. Yang penting, dalam ANC juga menyediakan kesempatan berkomunikasi yang efektif tentang masalah fisiologis, biomedis, perilaku dan sosial budaya, dukungan emosional dan psikologis pada ibu hamil dengan cara yang terhormat. Selain itu meminta dukungan keluarga dan komunitas selama masa kehamilan, persalinan dan nifas juga sangat diperlukan (WHO, 2016)

Penelitian terkait pelayanan antenatal terpadu di Indonesia belum banyak dilakukan. Evaluasi pelaksanaan program juga belum pernah dilakukan. Sehingga efektifitas program ini belum dapat didapatkan hasil. Seyogyanya apabila pelayanan antenatal terpadu ini dilaksanakan dengan baik oleh tenaga kesehatan, tentu saja angka kematian ibu akibat komplikasi masa kehamilan, persalinan dan nifas akan menurun.

Suvey pendahuluan yang dilakukan dengan cara wawancara di wilayah kerja Puskesmas Tembilahan Hulu, didapatkan hasil bahwa beberapa bidan belum mengetahui kriteria pelayanan antenatal 10 standar. Wawancara yang dilakukan dengan beberapa ibu hamil didapatkan hasil bahwa, ibu hamil tidak mendapatkan pelayanan antenatal lengkap 10 standar terutama konseling (temu wicara) setelah dilakukan pemeriksaan.

Cakupan kunjungan antenatal K1 dan K4 di Puskesmas Tembilahan Hulu terjadi peningkatan yang sangat signifikan dari tahun 2015 sebesar 40,50\% menjadi $82 \%$ pada tahun 2016, seperti yang terlihat pada tabel 1 berikut:

Tabel 1. Data Kunjungan K1 dan K4

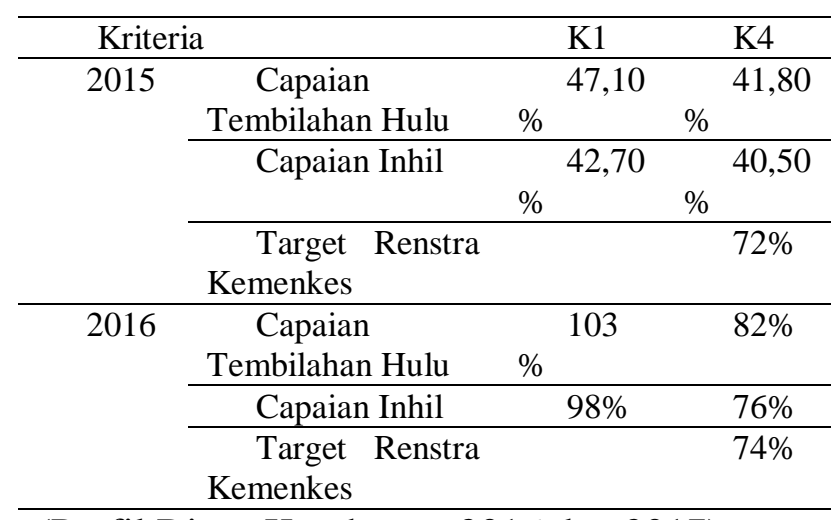

(Profil Dinas Kesehatan, 2016 dan 2017) 
Peningkatan tidak hanya terjadi di Puskesmas Tembilahan Hulu namun juga di Kabupaten Indragiri Hilir. Data ini memperlihatkan bahwa hampir semua ibu hamil di wilayah Puskesmas Tembilahan Hulu mendapatkan layanan kesehatan Antenatal. Peningkatan cakupan kunjungan antenatal ini tidak diikuti dengan peningkatan cakupan layanan antenatal perstandar. Dimana cakupan Fe3 hnaya 12\%, Skrining T5 28\%, HIV Testing 124 dari 6.516, TB Tsting 3 dari 754, dan tidak ada data yang memperlihatkan pelaksanaan standar tata laksana kasus (perkiraan ibu hamil dengan komplikasi 0\%).

Informasi yang tepat merupakan syarat mutlak untuk mendapatkan perencanaan program yang berkualitas dan tepat sasaran (Dirjen Kesmas, Kemenkes RI). Data dan informasi yang tidak akurat menyebabkan identifikasi penyebab masalah sulit ditentukan, dan pada akhirnya masalah kesehatan seperti AKI, AKB, dan lain-lain tidak ditangani secara tepat. Padahal salah satu upaya untuk menurunkan AKI dan AKB adalah adanya bentuk pencatatan informasi yang berkesinambungan yang dapat dipantau dan dievaluasi berdasarkan rencana aksi yang dapat ditetapkan oleh pemerintah melalui sistem informasi yang adekuat.

Beradsarkan uraian di atas, perlu dilakukan penelusuran data primer terkait permasalahan yang dihadapi dalam pelaksanaan pelayanan antenatal terpadu. Untuk itu, Tim Dosen Akbid Husada Gemilang bekerjasama dengan Dinas Kesehatan Kabupaten Indragiri Hilir ingin mengkaji permasalahan diatas secara ilmiah dengan melakukan penelitian ini.

Berdasarkan uraian latar belakang di atas, maka masalah yang dapat diidentifikasi adalah: bagaimana permasalahan pelayanan ANC Terpadu, dalam pelaksanaan ANC, dan faktor yang mempengaruhi pelaksanaan ANC terpadu di wilayah Kerja Puskesmas Tembilahan Hulu tahun 2018

\section{TINJAUAN PUSTAKA}

Antenatal Care (ANC) adalah pengawasan sebelum persalinan terutama ditujukan pada pertumbuhan dan perkembangan janin dalam rahim. Antenatal care juga merupakan cara penting untuk memonitoring dan mendukung kesehatan ibu hamil dan mendeteksi ibu dengan kehamilan normal, ibu hamil sebaiknya dianjurkan mengunjungi bidan atau dokter sedini mungkin semenjak ia merasa dirinya hamil untuk mendapatkan pelayanan dan asuhan antenatal (Prawiroharjo.s, 2006)

Pemeriksaan antenatal care (ANC) adalah pemeriksaan kehamilan untuk mengoptimalkan kesehatan mental dan fisik ibu hamil. Sehingga mampu menghadapi persalinan, kala nifas, persiapan pemberi ASI dan kembalinya kesehatan reproduksi secara wajar (Manuaba, 2008)

Pelayanan antenatal terpadu adalah pelayanan antenatal komprehensif dan berkualitas yang diberikan kepada semua ibu hamil yang bertujuan untuk: memenuhi hak setiap ibu hamil memperoleh pelayanan antenatal yang berkualitas sehingga mampu menjalani kehamilan dengan sehat, bersalin dengan selamat dan melahirkan bayi yang sehat dan berkualitas dengan cara 1) Menyediakan pelayanan antenatal terpadu, komprehensif dan berkualitas, termasuk konseling kesehatan dan gizi ibu hamil, konseling KB dan pemberian ASI; 2) Menghilangkan "missed opportunity" pada ibu hamil dalam mendapatkan pelayanan antenatal terpadu, komprehensif, dan berkualitas; 3) Mendeteksi secara dini kelainan/penyakit/gangguan yang diderita ibu hamil; 4) Melakukan intervensi terhadap kelainan/penyakit/gangguan pada ibu hamil sedini mungkin; dan 5) Melakukan rujukan kasus ke fasiltas pelayanan kesehatan sesuai dengan sistem rujukan yang ada (Kemenkes, 2015)

Permenkes RI nomor 43 tahun 2016 pasal 2 tentang Standar Pelayanan Minimal Bidang Kesehatan menyebutkan bahwa pernyataan standar pelayanan antenatal terpadu adalah "Setiap ibu hamil mendapatkan pelayanan antenatal sesuai standar. Pemerintah Daerah Kabupaten/Kota wajib memberikan pelayanan kesehatan ibu hamil kepada semua ibu hamil di wilayah kabupaten/kota tersebut dalam kurun waktu kehamilan".

Pelayanan antenatal sesuai standar adalah pelayanan yang diberikan kepada ibu hamil 
minimal 4 kali selama kehamilan dengan jadwal satu kali pada trimester pertama, satu kali pada trimester kedua dan dua kali pada trimester ketiga yang dilakukan oleh Bidan dan atau Dokter dan atau Dokter Spesialis Kebidanan baik yang bekerja di fasilitas pelayanan kesehatan pemerintah maupun swasta yang memiliki Surat Tanda Register (STR).

Dalam melakukan pemeriksaan antenatal, tenaga kesehatan harus

Memberikan pelayanan yang berkualitas sesuai standar terdiri dari 10 standar seperti yang diperlihatkan pada gambar 1 berikut:

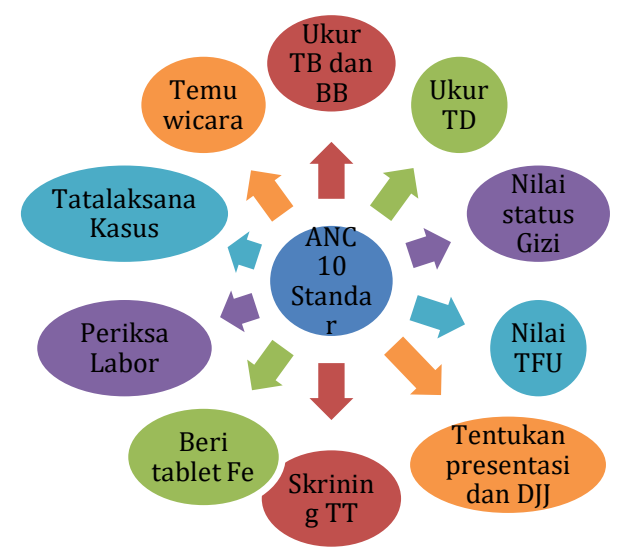

Gambar 1

10 Standar Pelayanan Antenatal Terpadu

\section{1) Timbang berat badan dan ukur tinggi badan}

Penimbangan berat badan pada setiap kali kunjungan antenatal dilakukan untuk mendeteksi adanya gangguan pertumbuhan janin. Penambahan berat badan yang kurang dari 9 kilogram selama kehamilan atau kurang dari 1 kilogram setiap bulannya menunjukkan adanya gangguan pertumbuhan janin. Pengukuran tinggi badan pada pertama kali kunjungan dilakukan untuk menapis adanya faktor risiko pada ibu hamil. Tinggi badan ibu hamil kurang dari $145 \mathrm{~cm}$ meningkatkan risiko untuk terjadinya CPD (Cephalo Pelvic Disproportion)

\section{2) Ukur Tekanan darah}

Pengukuran tekanan darah pada setiap kali kunjungan antenatal dilakukan untuk mendeteksi adanya hipertensi (tekanan darah $\geq 140 / 90 \mathrm{mmHg}$ ) pada kehamilan dan preeklampsia (hipertensi disertai edema wajah dan atau tungkai bawah; dan atau proteinuria)

\section{3) Ukur lingkar lengan atas /LiLA}

Pengukuran LiLA hanya dilakukan pada kontak pertama oleh tenaga kesehatan di trimester I untuk skrining ibu hamilberisiko KEK. Kurang energi kronis disini maksudnya ibu hamil yang mengalami kekurangan gizi dan telah berlangsung lama (beberapa bulan/tahun) dimana LiLA kurang dari 23,5 $\mathrm{cm}$. Ibu hamil dengan KEK akan dapat melahirkan bayi berat lahir rendah (BBLR).

\section{4) Ukur Tinggi fundus uteri}

Pengukuran tinggi fundus pada setiap kali kunjungan antenatal dilakukan untuk mendeteksi pertumbuhan janin sesuai atau tidak dengan umur kehamilan. Jika tinggi fundus tidak sesuai dengan umur kehamilan, kemungkinan ada gangguan pertumbuhan janin. Standar pengukuran menggunakan pita pengukur setelah kehamilan 24 minggu.

\section{5) Tentukan presentasi janin dan denyut jantung janin (DJJ)}

Menentukan presentasi janin dilakukan pada akhir trimester II dan selanjutnya setiap kali kunjungan antenatal. Pemeriksaan ini dimaksudkan untuk mengetahui letak janin. Jika, pada trimester III bagian bawah janin bukan kepala, atau kepala janin belum masuk ke panggul berarti ada kelainan letak, panggul sempit atau ada masalah lain. Penilaian DJJ dilakukan pada akhir trimester I dan selanjutnya setiap kali kunjungan antenatal. DJJ lambat kurang dari 120 $\mathrm{kali} /$ menit atau DJJ cepat lebih dari 160 kali/menit menunjukkan adanya gawat janin.

6) Skrining Status Imunisasi Tetanus dan berikan imunisasi Tetanus Toksoid (TT) bila diperlukan 
Untuk mencegah terjadinya tetanus neonatorum, ibu hamil harus mendapat imunisasi TT. Pada saat kontak pertama, ibu hamil diskrining status imunisasi T-nya. Pemberian imunisasi TT pada ibu hamil, disesuai dengan status imunisasiTibu saat ini. Ibu hamil minimalmemiliki status imunisasi T2 agar mendapatkan perlindungan terhadap infeksi tetanus. Ibu hamil dengan status imunisasi T5 (TTLong Life) tidak perlu diberikan imunisasi TT lagi. Pemberian imunisasi TT tidak mempunyai interval maksimal, hanya terdapat interval minimal.

\section{7) Beri Tablet tambah darah (tablet besi)}

Untuk mencegah anemia gizi besi, setiap ibu hamil harus mendapat tablet tambah darah (tablet zat besi)dan Asam Folat minimal 90 tablet selama kehamilan yang diberikan sejak kontak pertama.

\section{8) Periksa laboratorium (rutin dan khusus)}

Pemeriksaan laboratorium yang dilakukan pada ibu hamil adalah pemeriksaan laboratorium rutin dan khusus. Pemeriksaan laboratorium rutin adalah pemeriksaan laboratorium yang harus dilakukan pada setiap ibu hamil yaitu golongan darah, hemoglobin darah, dan pemeriksaan spesifik daerah endemis/epidemi (malaria, HIV, dll). Sementara pemeriksaan laboratorium khusus adalah pemeriksaan laboratorium lain yang dilakukan atas indikasi pada ibu hamil yang melakukan kunjungan antenatal. Pemeriksaan laboratorium dilakukan pada saat antenatal tersebut meliputi:

a) Pemeriksaan golongan darah

Pemeriksaan golongan darah pada ibu hamil tidak hanya untuk mengetahui jenis golongan darah ibu melainkan jugauntuk mempersiapkan calon pendonor darah yang sewaktu-waktu diperlukan apabila terjadi situasi kegawatdaruratan.

b) Pemeriksaan kadar Hemoglobin darah ( $\mathrm{Hb})$

Pemeriksaan kadar hemoglobin darah ibu hamil dilakukan minimal sekali pada trimester pertama dan sekali pada trimester ketiga. Pemeriksaan ini ditujukan untuk mengetahui ibu hamil tersebut menderita anemia atau tidak selama kehamilannya karena kondisi anemia dapat mempengaruhi proses tumbuh kembang janin dalam kandungan. Pemeriksaan kadarhemoglobin darah ibu hamil pada trimester kedua dilakukan atas indikasi.

c) Pemeriksaan protein dalam urin

Pemeriksaan protein dalam urin pada ibu hamil dilakukan pada trimester kedua dan ketiga atas indikasi. Pemeriksaan ini ditujukan untuk mengetahui adanya proteinuria pada ibu hamil. Proteinuria merupakan salah satu indikator terjadinya pre-eklampsia pada ibu hamil.

d) Pemeriksaan kadar gula darah.

Ibu hamil yang dicurigai menderita diabetes melitus harus dilakukan pemeriksaan gula darah selama kehamilannya minimal sekali pada trimester pertama, sekali pada trimester kedua, dan sekali pada trimester ketiga.

e) Pemeriksaan darah Malaria

Semua ibu hamil di daerah endemis Malaria dilakukan pemeriksaan darah Malaria dalam rangka skrining pada kontak pertama. Ibu hamil di daerah non endemis Malaria dilakukan pemeriksaan darah Malaria apabila ada indikasi.

f) Pemeriksaan tes Sifilis

Pemeriksaan tes sifilis dilakukan di daerah dengan risiko tinggi dan ibu hamil yang diduga menderita sifilis. Pemeriksaaan sifilis sebaiknya dilakukan sedini mungkin pada kehamilan.

g) Pemeriksaan HIV

Di daerah epidemi HIV meluas dan terkonsentrasi, tenaga kesehatan di fasilitas pelayanan kesehatan wajib menawarkan tes HIV kepada semua ibu hamil secara inklusif pada pemeriksaan laboratorium rutin lainnya saat pemeriksaan antenatal atau menjelang persalinan. Di daerah epidemi HIV rendah, penawaran tes HIV oleh tenaga kesehatan diprioritaskan pada ibu hamil dengan IMS dan TB secara inklusif pada pemeriksaan laboratorium rutin lainnya saat pemeriksaan antenatal atau menjelang 
persalinan Teknik penawaran ini disebut Provider Initiated Testing and Councelling (PITC) atau Tes HIV atas Inisiatif Pemberi Pelayanan Kesehatan dan Konseling (TIPK)

h) Pemeriksaan BTA

Pemeriksaan BTA dilakukan pada ibu hamil yang dicurigai menderita tuberkulosis sebagai pencegahan agar infeksi tuberkulosis tidak mempengaruhi kesehatan janin. Selain pemeriksaaan tersebut diatas, apabila diperlukan dapat dilakukan pemeriksaan penunjang lainnya di fasilitas rujukan.

Mengingat kasus perdarahan dan preeklamsi/eklamsi merupakan penyebab utama kematian ibu, maka diperlukan pemeriksaan dengan menggunakan alat deteksi risiko ibu hamil oleh bidan termasuk bidan desa meliputi alat pemeriksaan laboratorium rutin (golongan darah, $\mathrm{Hb}$ ), alat pemeriksaan laboratorium khusus (gluko-protein urin), dan tes hamil.

\section{9) Tatalaksana/penanganan Kasus}

Berdasarkan hasil pemeriksaan antenatal di atas dan hasil pemeriksaan laboratorium, setiap kelainan yang ditemukan pada ibu hamil harus ditangani sesuai dengan standar dan kewenangan tenaga kesehatan. Kasuskasus yang tidak dapat ditangani dirujuk sesuai dengan sistem rujukan.

\section{0) Temu wicara (konseling)}

Temu wicara (konseling) dilakukan pada setiap kunjungan antenatal yang meliputi :

a) Kesehatan ibu

Setiap ibu hamil dianjurkan untuk memeriksakan kehamilannya secara rutin ke tenaga kesehatan dan menganjurkan ibu hamil agar beristirahat yang cukup selama kehamilannya (sekitar 9-10 jam per hari) dan tidak bekerja berat.

b) Perilaku hidup bersih dan sehat

Setiap ibu hamil dianjurkan untuk menjaga kebersihan badan selama kehamilan misalnya mencuci tangan sebelum makan, mandi 2 kali sehari dengan menggunakan sabun, menggosok gigi setelah sarapan dan sebelum tidur serta melakukan olah raga ringan.

c) Peran suami/keluarga dalam kehamilan dan perencanaan persalinan

Setiap ibu hamil perlu mendapatkan dukungan dari keluarga terutama suami dalam kehamilannya. Suami, keluarga atau masyarakat perlu menyiapkan biaya persalinan, kebutuhan bayi, transportasi rujukan dan calon donor darah. Hal ini penting apabila terjadi komplikasi kehamilan, persalinan, dan nifas agar segera dibawa ke fasilitas kesehatan.

d) Tanda bahaya pada kehamilan, persalinan dan nifas serta kesiapan menghadapi komplikasi

Setiap ibu hamil diperkenalkan mengenal tanda-tanda bahaya baik selama kehamilan, persalinan, dan nifas misalnya perdarahan pada hamil muda maupun hamil tua, keluar cairan berbau pada jalan lahir saat nifas, dsb. Mengenal tandatanda bahaya ini penting agar ibu hamil segera mencari pertolongan ke tenaga kesehtan kesehatan.

e) Asupan gizi seimbang

Selama hamil, ibu dianjurkan untuk mendapatkan asupan makanan yang cukup dengan pola gizi yang seimbang karena hal ini penting untuk proses tumbuh kembang janin dan derajat kesehatan ibu. Misalnya ibu hamil disarankan minum tablet tambah darah secara rutin untuk mencegah anemia pada kehamilannya.

f) Gejala penyakit menular dan tidak menular.

Setiap ibu hamil harus tahu mengenai gejala-gejala penyakit menular dan penyakit tidak menular karena dapat mempengaruhi pada kesehatan ibu dan janinnya.

g) Penawaran untuk melakukan tes HIV dan Konseling di daerah Epidemi meluas dan terkonsentrasi atau ibu hamil dengan IMS dan TB di daerah epidemic rendah.

Setiap ibu hamil ditawarkan untuk dilakukan tes HIV dan segera diberikan informasi mengenai resiko penularan HIV dari ibu ke janinnya. Apabila ibu hamil 
tersebut HIV positif maka dilakukan konseling Pencegahan Penularan HIV dari Ibu ke Anak (PPIA). Bagi ibu hamil yang negatif diberikan penjelasan untuk menjaga tetap HIV negatif diberikan penjelasan untuk menjaga HIV negative selama hamil, menyusui dan seterusnya.

h) Inisiasi Menyusu Dini (IMD) dan pemberian ASI ekslusif

Setiap ibu hamil dianjurkan untuk memberikan ASI kepada bayinya segera setelah bayi lahir karena ASI mengandung zat kekebalan tubuh yang penting untuk kesehatan bayi. Pemberian ASI dilanjutkan sampai bayi berusia 6 bulan.

i) $\mathrm{KB}$ paska persalinan

Ibu hamil diberikan pengarahan tentang pentingnya ikut $\mathrm{KB}$ setelah persalinan untuk menjarangkan kehamilan dan agar ibu punya waktu merawat kesehatan diri sendiri, anak, dan keluarga.

j) Imunisasi

Setiap ibu hamil harus mempunyai status imunisasi (T) yang masih memberikan perlindungan untuk mencegah ibu dan bayi mengalami tetanus neonatorum. Setiap ibu hamil minimal mempunyai status imunisasi T2 agar terlindungi terhadap infeksi tetanus.

k) Peningkatan kesehatan intelegensia pada kehamilan (Brain booster)

Untuk dapat meningkatkan intelegensia bayi yang akan dilahirkan, ibu hamil dianjurkan untuk memberikan stimulasi auditori dan pemenuhan nutrisi pengungkit otak (brain booster) secara bersamaan pada periode kehamilan.

Untuk menyelenggarakan pelayanan antenatal terpadu diperlukan suatu manajemen berbasis data. Kementerian Kesehatan menetapkan norma, standar, prosedur dan kriteria (NSPK) untuk pelayanan antenatal terpadu, termasuk melakukan advokasi, fasilitasi, pendampingan, koordinasi, pemantauan dan evaluasi penyelenggaraan dan pelayanan antenatal terpadu.

\section{1) Input}

Input yang diperlukan untuk menyelenggarakan pelayanan antenatal terpadu antara lain meliputi:

a) Adanya norma, standar, prosedur dan kriteria (NSPK) pelayanan antenatal terpadu.

b) Adanya perencanaan dan penganggaran tahunantingkat pusat, provinsi dan kabupaten/kota untuk penyelenggaraan pelayanan antenatal terpadu di fasilitas pelayanan kesehatan.

c) Adanya sarana dan fasilitas kesehatan sesuai standar dalam menyelenggarakan pelayanan antenatal terpadu.

d) Adanya logistik yang dibutuhkan untuk mendukung penyelenggaraan pelayanan antenatal terpadu.

e) Adanya tenaga pengelola program KIA yang sesuai untuk mengelola pelayanan antenatal terpadu di tingkat propinsi dan kabupaten/kota.

f) Adanya tenaga kesehatan untuk memberikan pelayanan antenatal terpadu sesuai standar.

g) Adanya informasi sistem dan tempat rujukan bagi masing-masing kasus dalam pelaksanaan pelayanan antenatal terpadu.

h) Adanya informasi status endemisitas dan daerah berisiko tinggi penyakit yang mempengaruhi kehamilan.

i) Adanya pedoman pelaksanaan program terkait dengan pelayanan antenatal terpadu.

\section{2) Proses}

a) Sosialisasi norma, standar, prosedur dan kriteria (NSPK) pelayanan antenatal terpadu secara berjenjang.

b) Penyusunan perencanaan dan penganggaran program KIA tahunantingkat pusat, provinsi dan kabupaten/kota untuk penyelenggaraan pelayanan antenatal terpadu di fasilitas pelayanan kesehatan.

c) Melaksanakan pelayanan antenatal terpadu disarana dan fasilitas kesehatan 
d) Menggunakan logistik sesuai kebutuhan dalam penyelenggaraan pelayanan antenatal terpadu.

e) Standarisasi pengelola program KIA dalam penyelenggaraan pelayanan antenatal terpadu di tingkat propinsi dan kabupaten/kota.

f) Standarisasi tenaga kesehatan dalam memberikan pelayanan antenatal terpadu

g) Menggunakan informasi, sistem dan tempat rujukan kasus dalam pelaksanaanpelayanan antenatal terpadu

h) Menggunakan informasi endemisitas dan daerah berisiko tinggi terjadinya penyakit terkait kehamilan dalam memberikan pelayanan antenatal terpadu.

i) Menggunakanpedoman pelaksanaan program terkait dalam menyelenggarakan pelayanan antenatal terpadu

\section{3) Output}

a) Tersosialisasinya norma, standar, prosedur dan kriteria (NSPK) pelayanan antenatal terpadu

b) Terlaksananya pelayanan antenatal terpadu di fasilitas pelayanan kesehatan sesuai perencanaan yang didukung anggaran tahunan di tingkat pusat, provinsi dan kabupaten/kota.

c) Terlaksananya pelayanan antenatal terpadu disarana dan fasilitas kesehatan yang telah terstandar.

d) Digunakannya logistik pendukung yang dibutuhkan dalam penyelenggaraan pelayanan antenatal terpadu.

e) Tenaga pengelola program KIA mampu mengelola pelayanan antenatal terpadu di tingkat propinsi dan kabupaten/kota.

f) Tenaga kesehatan mampu memberikan pelayanan antenatal terpadu sesuai standar.

g) Digunakannya informasi sistem dan tempat rujukan dalam pelaksanaanpelayanan antenatal terpadu. Pelayanan antenatal terpadu terlaksana sesuai dengan status endemisitas dan daerah berisiko tinggi penyakit yang mempengaruhi kehamilan. h) Digunakan informasi endemisitas dan daerah berisiko tinggi terjadinya penyakit terkait kehamilan dalam memberikan pelayanan antenatal

i) Digunakan pedoman pelaksanaan program terkait dalam menyelenggarakan pelayanan antenatal terpadu

\section{METODE}

Penelitian ini menggunakan strategi eksploratoris sekuensial, yaitu metode penelitian yang dimulai dnegan pengumpulan data dan analisis data kualitatif kemudian diikuti dengan pengumpulan data dan analisis kuantitaif. Rancangan kualitatif dengan menggunakan pendekatan fenomenologis, yaitu kebenaran sesuatu itu diperoleh dengan cara menangkap fenomena atau gejala yang memancar dari objek yang diteliti. Semua aspek yang menjadi permasalahan dalam pelaksanaan pelayanan ANC terpadu ditelusuri dengan FGD dan wawancara mendalam.

Setelah didapatkan permasalahan dan faktor-faktor yang mempengaruhi, kemudian hasilnya dikonfirmasi melalui penelitian kuantitatif. Rancangan kuantitatif menggunakan pendekatan cross-sectional. Penelitian ini digunakan untuk mengeneralkan permasalahan dalam pelaksanaan pelayanan ANC Terpadu.

Penelitian dilaksanakan di wilayah kerja Puskesmas Tembilahan Hulu pada bulan Oktober s/d Desember 2018.

Teknik pengambilan sampel pada responden ibu hamil adalah purposive sampling yaitu suatu teknik penetapan sampel dengan cara memilih sampel diantara populasi sesuai dengan yang dikehendaki peneliti (tujuan/ masalah dalam penelitian) (Nursalam, 2013). Pengambilan sampel responden ibu hamil dalam penelitian ini dihitung dengan menggunakan rumus besar sampel estimasi proporsi untuk simpangan mutlak sebanyak 138 ibu hamil. Sedangkan untuk sampel bidan, teknik sampling dilakukan secara total sampling yaitu seluruh populasi dijadikan sampel penelitian yang berjumlah 42 orang bidan.

Data yang digunkaan pada penelitian ini adalah kuantitatif dan kualitatif. Dimana 
pengumpulan data kualitatif menggunakan dua metode, yaitu FGD dan wawancara mendalam. FGD dilakukan untuk menggali aspek-aspek yang berhubungan dengan permasalahan dalam pelaksanaan pelayanan antenatal terpadu baik itu di puskesmas maupun di puskesmas pembantu.

Hasil FGD selanjutnya akan digali lebih dalam melalui wawancara mendalam. Empat fasilitator dan empat notulen telah direkrut dan dilatih untuk mengumpulkan informasi dari bidan. Diharapkan 42 bidan yang diundang dapat mengikuti kegiatan FGD yang selanjutnya dikelompokkan menjadi empat kelompok. Setiap kelompok terdiri dari 10-11 bidan yang dipandu oleh satu orang fasilitator dan satu orang notulen.

Hasil FGD dijadikan sebagai dasar dalam membangun panduan wawancara. Wawancara mendalam dilakukan untuk menggali hambatan individu bidan dalam menjalankan tugas pokok dan fungsinya sebagai bidan. Wawancara mendalam dilakukan oleh dua orang yang telah terlatih dan berpengalaman dalam penelitian kualitatif. Diharapkan wawancara mendalam dilakukan secara face to face dilakukan di rumah partisipan, rumah pewawancara, tempat kerja pewawancara, dan tempat lainnya disesuaikan dengan keinginan partisipan. Wawancara juga dapat dilakukan melalui telepon karena alasan tertentu. Wawancara mendalam difokuskan pada pengalaman individual yang dihadapi oleh bidan dalam melaksanakan pelayanan antenatal terpadu. Hasil wawancara selanjutnya diolah dan diverifikasi.

Verifikasi data dilakukan dengan triangulasi data. Sebanyak 3 wawancara mendalam tambahan, yaitu pada 1 kepala puskesmas, 1 penanggung jawab progran, dan 1 bidan koordinator dilakukan untuk membantu verifikasi data. Untuk mengeneralkan permasalahan tersebut, hasil analisis data FGD dan wawancara secara mendalam dibuat dalam bentuk angket yang kemudian disebarkan pada seluruh bidan di wilayah kerja Puskesmas Tembilahan Hulu. Hasil angket selanjutnya dianalisi secara kuantitatif.
Pengumpulan data kualitatif pada ibu hamil dilakukan dengan teknik wawancara dengan menggunakan panduan wawancara. Wawancara dilakukan untuk menggali aspek aspek pelayanan yang diterima ibu hamil pada saat memeriksakan kehamilannya. Wawancara dilakukan face to face di lakukan di rumah pasien atau di puskesmas setelah pasien mendapat pelayanan antenatal.

Setelah data terkait pelayanan yang didapatkan ibu hamil selama ANC, selanjutnya data dianalisis secara kuantitatif dengan pendekatan cross sectional

\section{HASIL DAN PEMBAHASAN}

Isi Hasil dan Pembahasan

Setelah dilakukan penelitian dengan judul "Analisis Pelaksanaan Pelayanan Antenatal Terpadu 10 Standar di Puskesmas Tembilahan Hulu Tahun 2018" didapatkan hasil sebagai berikut:

Tabel 2 Karakteristik Responden

\begin{tabular}{|c|c|c|c|}
\hline $\mathbf{0}^{\mathbf{N}}$ & Kategori & $\mathbf{F}$ & $\%$ \\
\hline \multicolumn{4}{|c|}{ Responden Ibu Hamil } \\
\hline \multirow[t]{10}{*}{1} & Pendidikan & & \\
\hline & $\mathrm{SD}$ & 27 & 19,5 \\
\hline & SMP & 44 & 7 \\
\hline & SMA & 47 & 31,8 \\
\hline & PT & 20 & 8 \\
\hline & Jumlah & 13 & 34,0 \\
\hline & & 8 & \\
\hline & & & 14,4 \\
\hline & & & 9 \\
\hline & & & 100 \\
\hline \multicolumn{4}{|c|}{ Responden Bidan } \\
\hline \multirow[t]{8}{*}{2} & Umur (tahun) & & \\
\hline & $21-30$ & 20 & 47,6 \\
\hline & $31-40$ & 14 & 2 \\
\hline & $41-50$ & 8 & 33,3 \\
\hline & Jumlah & 42 & 3 \\
\hline & & & 19,0 \\
\hline & & & 5 \\
\hline & & & 100 \\
\hline \multirow[t]{6}{*}{3} & Pendidikan & & \\
\hline & DIII Kebidanan & 24 & 57,1 \\
\hline & DV Kebidanan & 18 & 4 \\
\hline & Jumlah & 42 & 42,8 \\
\hline & & & 6 \\
\hline & & & 100 \\
\hline \multirow[t]{2}{*}{4} & Status Pekerjaan & & \\
\hline & Honorer & 24 & 57,1 \\
\hline
\end{tabular}




\begin{tabular}{clcl}
\hline & ASN & 18 & 4 \\
& Jumlah & 42 & 42,8 \\
& & 6 \\
& & 100 \\
\hline 5 & Tempat Bekerja & & \\
& Pustu & 24 & 57,1 \\
& UPT Puskesmas & 18 & 4 \\
& Jumlah & 42 & 42,8 \\
& & 6 \\
& & 100 \\
\hline 6 & Lama Bekerja (tahun) & & \\
& $0-1$ & & 11,9 \\
& $2-5$ & 5 & 19,5 \\
$6-10$ & 8 & 42,8 \\
& $11-20$ & 18 & 6 \\
& & 6 & 14,2 \\
& Jumlah & 5 & 9 \\
& & 42 & 11,9 \\
& & & 100 \\
\hline
\end{tabular}

Sumber : Data Primer 2018

Tabel 2 diatas memperlihatkan bahwa karakteristik responden ibu hamil berdasarkan pendidikan sebagian besar adalah SMP $(31,88 \%)$ dan SMA (34,06\%). Sedangkan karakteristik responden bidan sebagian besar berdasarkan umur adalah 21- 30 tahun sebanyak 47,62\%, pendidikan D3 kebidanan $57,14 \%$, status pekerjaan sebagai honorer $57,14 \%$, tempat bekerja di puskesmas pembantu $57,14 \%$, dan lama bekerja 11-20 tahun $42,86 \%$.

Pelaksanaan 10 standar ANC dilihat berdasarkan pelaksanaan masing-masing standar disajikan pada gambar 2 berikut:

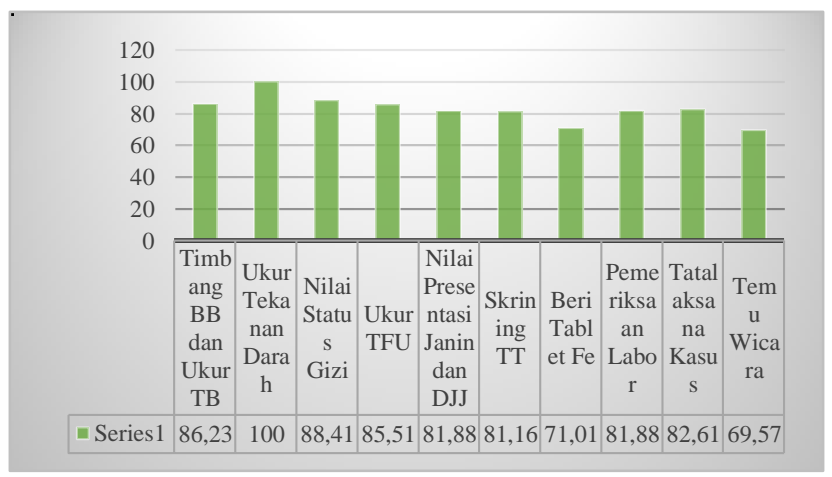

Gambar 2 Pelaksanaan 10 Standar ANC
Gambar 2 diatas memperlihatkan bahwa semua ibu hamil diperiksa tekanan darahnya sebanyak (100\%) dan paling sedikit temu wicara sebanyak $(69,57 \%)$.

Jika dilihat berdasarkan kelengkapan pelayanan yang diterima responden didapatkan hasil seperti pada gambar 3 berikut:

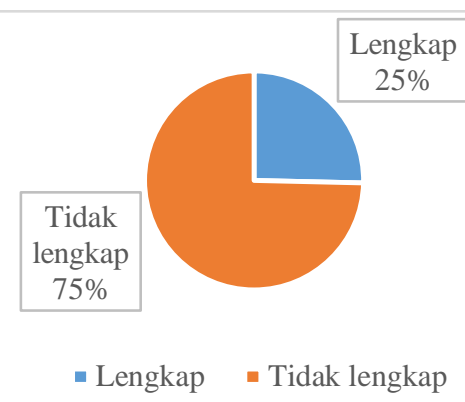

Gambar 3 Kelengkapan Pelayanan ANC 10 Standar

Gambar 3 diatas memperlihatkan bahwa responden yang mendapatkan pelayanan ANC terpadu lengkap 10 standar hanya 25\% (35 orang).

Hasil wawancara mendalam terkait permasalahan dalam pelaksanaan 10 standar ANC adalah sebagai berikut:

Tabel 3 Hambatan bidan dalam pelaksanaan 10 standar ANC

\begin{tabular}{ll}
\hline No & Hambatan \\
\hline 1 & Sarana dan Prasarana \\
& 1) Peralatan tidak memadai \\
& 2) Sebagian alat rusak dan tdaik diperbaiki \\
& 3) Alat pemeriksaan labor tidak lengkap \\
& 4) Stik pemeriksaan protein dan glukosa tidak \\
& ada \\
\hline 2 & Kompetensi dan jumlah Tenaga Kesehatan \\
& (Bidan)
\end{tabular}

1) Bidan tidak terampil melakukan pemeriksaan

2) Lemahnya kemampuan bidan bernegosiasi dengan tokoh masyarakat

3) Jumlah tenaga kesehatan kurang

4) $47,62 \%$ mendapat bimtek pelayanan ANC 


\begin{tabular}{ll}
\hline & 10 standar, sisanya hanya mendengar dan \\
mendapat penjelasan teman sejawat \\
5) \\
Lemahnya kemampuan bidan mengisi \\
buku KIA
\end{tabular}

Sumber: Data Primer 2018

Berdasarkan hasil penelitian didapatkan bahwa hanya 35 orang (25\%) ibu hamil mendapatkan pelayanan ANC dengan lengkap 10 standar. Meskipun jika dilihat per masingmasing standar, sebagian besar standar ANC telah dilaksanakan. Seperti dapat dilihat bahwa $100 \%$ ibu hamil dilakukan pemeriksaan tekanan darah.

Namun hal ini tidak cukup, karena untuk mendapatkan pelayanan ANC yang berkualitas, setiap ibu hamil harus mendapatkan seluruh standar.

Hasil wawancara mendalam, didapatkan kendala petugas kesehatan dalam menjalankan standar tersebut, diantaranya keterbatasan sarana dan prasarana seperti, ketidaklengkapan alat, alat-alat yang rusak dan tidak diganti atau dilakukan perbaikan.

Sarana dan prasarana yang memadai merupakan syarat mutlat dalam pelayanan ANC terpadu yang berkualitas (Permenkes RI nomor 97 tahun 2014).

Standarisasi tenaga kesehatan dalam memberikan pelayanan antenatal terpadu juga merupakan hal yang mutlak (Permenkes RI nomor 97 tahun 2014). Hasil penelitian diketahui bahwa hanya $47,62 \%$ bidan yang mendapatkan bimtek pelayanan ANC terpadu dengan 10 standar. Sisanya hanya mendapat informasi dari teman sejawat.
Diketahui bahwa bimbingan dan pelatihan sangat diperlukan untuk meningkatkan kompetensi petugas dalam memberikan pelayanan.

\section{KESIMPULAN}

Sebanyak 25\% (35 orang ibu hamil) mendapatakan pelayanan ANC lengkap 10 standar. Standar yang paling lengkap dilakukan adalah pengukuran tekanan darah yaitu $100 \%$. Masalah dalam pelaksanaan 10 standar ANC adalah sarana dan prasarana yang kurang memadai, kompetensi dan jumlah tenaga kesehatan (bidan), serta demografi dan budaya masayarakat setempat.

\section{DAFTAR PUSTAKA}

[1] Arman, Niken (2016) 'Analisis Pelaksanaan Program Antenatal Terpadu di Puskesmas Bandarharjo Kota Semarang', Skripsi, Jurusan Ilmu Kesehatan Masyarakat: Fakultas Ilmu Keolahragaan Universitas Negeri Semarang

[2] Azwar, A. (2008) 'Pengantar Administrasi Kesehatan Masyarakat', Semarang: Universitas Diponegoro

[3] Dinkes, Inhil. (2017) 'Profil Kesehatan Kabupatem Imdragiri Hilir tahun 2016' Tembilahan: Dinas Kesehatan Kabupaten Indragiri Hilir

[4] Dinkes, Inhil. (2018) 'Profil Kesehatan Kabupatem Imdragiri Hilir tahun 2017' Tembilahan: Dinas Kesehatan Kabupaten Indragiri Hilir

[5] Indrayani and Mulyawati, G. (2015) 'Village midwives' experiences in rural area', Jurnal Ilmiah Permata Medika, 4(1), pp. 1-24. doi: 10.5281/zenodo.1322413.

[6] Kemenkes, R. (2015) Profil Kesehatan 
RI 2015, Profil Kesehatan Indonesia Tahun 2015. doi: 10.1111/evo.12990.

[7] Kemenkes, R. I. (2016) 'Peraturan Menteri Kesehatan Republik Indonesia no,43 tahun 2016 tentang standar pelayanan minimal bidang kesehatan', 31 Agustus 2016. Available at: https://djsn.go.id/storage/app/uploads/p ublic/58d/486/f01/58d486f010a3f0671 08647.pdf\%0Ahttp://djsn.go.id/storage /app/uploads/public/58d/486/f01/58d48 6f010a3f067108647.pdf.

[8] Kemenkes, R. I (2015) Peraturan Menteri Kesehatan Republik Indonesia nomor 97 tahun 2014 tentang pelayanan kesehatan masa sebelum hamil, masa hamil, persalinan, dan masa sesudah melahirkan, penyelenggaraan pelayanan kontrasepsi, serta pelayanan kesehatan seksual', Jakarta: Kemeterian Kesehatan Republik Indonesia

[9] Kemenkes, R. I (2016) 'Rencana Strategis Program Direktorat Jenderal Bina Gizi dan KIA tahun 2015-2019', Jakarta: Direktorat Bina Gizi dan KIA, Kementerian Kesehatan Republik Indonesia

[10]Lapau (2012). Metode Penelitian Kesehatan, Metode Ilmiah Penulisan Skripsi, Tesis, dan Disertasi, Yayasan Pustaka Obor Indonesia: Jakarta

[11] Manuaba (2008) 'Universitas Sumatera Utara 4'.

[12] Mikrajab, M. A. and Rachmawati, T. (2016) 'Analisis Kebijakan Implementasi Antenatal Care Terpadu Puskesmas Di Kota Blitar (Policy Analysis of Integrated Antenatal Care implementation at Public Health Centers in Blitar City)', Buletin Penelitian Sistem Kesehatan, 19(1), pp. 41-53. doi: 10.22435/hsr.v19i1.4988.41-53.

[13] Notoatmodjo, Soekidjo, (2010). Metodologi Penelitian Kesehatan. Jakarta : Rineka Cipta

[14] Prawiroharjo.s (2006) 'safe motherhood dan ANC', p. 52.
Available at: https://www.academia.edu/19217422/s afe motherhood_dan_ANC?auto=dow nload

[15] Sugiono (2008) 'Metode Penelitian Kuantitatif, Kualitatif dan R\&D', Bandung: Alfabet

[16] Satrianegara F, Saleha S (2009) 'Organisasi dan Manajemen Pelayanan Kesehatan Serta Kebidanan' Jakarta: Penerbit Salemba Medika

[17] WHO (2016) 'WHO Recommendation on Antenatal care for positive pregnancy experience', WHO Recommendation on Antenatal care for positive pregnancy experience, p. 152. doi: ISBN 9789241549912. 